\title{
EDITORIAL
}

\section{Dengue and other Aedes-borne viruses: a threat to Europe?}

\section{G Rezza ${ }^{1}$}

1. Department of Infectious, Parasitic, and Immunomediated Diseases, Istituto Superiore di Sanità, Roma, Italy

\section{Correspondence: Giovanni Rezza (giovanni.rezza@iss.it)}

Rezza G. Dengue and other Aedes-borne viruses: a threat to Europe?. Euro Surveill. 2016;21(21):pii=30238. DOI: http://dx.doi.org/10.2807/1560-7917. ES.2016.21.21.30238

At the beginning of the $20^{\text {th }}$ century, dengue outbreaks were rather common in the Mediterranean basin. The last major epidemic on the European continent occurred in 1927/28 and predominantly affected Athens and neighbouring areas of Greece. After a first mild wave, which nearly ended with the arrival of cold weather in the winter season, a small number of cases continued to occur through the winter and spring, increasing dramatically in August 1928 [1-3]. It is conceivable that both the virus and its primary vector, the Aedes aegypti mosquito, survived the winter in the city, inside heated houses. Serological surveys detected neutralising antibodies to different dengue virus (DENV) serotypes in samples of individuals living in Athens in that period $[4,5]$. Some time after this severe outbreak, with 1,000 to 1,500 deaths, both dengue and its primary vector 'abandoned' the European continent.

The outbreak of seven autochthonous dengue cases reported by Succo et al. in this issue of Eurosurveillance [6] was triggered by one infected traveller returning from French Polynesia in the summer of 2015, and occurred in an area where another vector, Ae. albopictus, the Asian Tiger mosquito, was established in 2005.

This is not the first event of local transmission of DENV reported in Europe in recent years. Since 2010, at least 23 dengue cases were detected. In September 2010, two autochthonous cases of dengue fever were identified in Nice, southern France. The index case had friends from the West French Indies staying with him, while the second case was an individual living nearby [7]. In the summer of the same year, another transmission event occurred in Croatia $[8,9]$. The index case was a German man returning in mid-August from a two-week holiday spent at the Peljesac peninsula and the isle of Korĉula, ca $100 \mathrm{~km}$ north-west of Dubrovnik. A second autochthonous case, and other 15 individuals with serological evidence of recent infection, were identified in October 2010. How the virus was introduced in Croatia remains unclear. In 2013 and 2014, five autochthonous case of dengue were identified in southern France, one in Bouches-du-Rhône (2013) [10], and four in Aubage and Toulon-Hires (2014) [11]. Ae. albopictus was the vector in all the transmission events listed here.

Dengue is not the only Aedes-borne viral disease threatening the health of European citizens. Nearly 10 years ago, in the summer of 2007 , more than 250 cases of chikungunya occurred in the north-east of Italy [12]. The primary case was a viraemic individual arriving from the Indian State of Kerala. The chikungunya virus (CHIKV) implicated in the sustained outbreak carried the A226V mutation, which increases virus fitness and is usually detected in areas where the Tiger mosquito is the predominant vector [13]. In September 2010, autochthonous transmission of the CHIKV was also identified in south-east France, where chikungunya was diagnosed in two children living in the same area as another child who developed a febrile illness after returning from Rajasthan, India [14].

At present, there is concern about the possible emergence of Zika virus, which has been recently declared a 'Public Health Emergency of International Concern' by the World Health Organization [15]. Whether the increased risk of mosquito-borne transmission during the summer season in Europe will materialise in form of Aedes-borne autochthonous cases of Zika virus infections is unknown.

With the exception of a large dengue outbreak with over 2,100 cases that occurred from October 2012 to March 2013 in the subtropical archipelago of Madeira, located in the Atlantic Ocean at around 1,000 km from mainland Portugal, where Ae. aegypti is largely predominant [16], the vector involved in local transmission of DENV and CHIKV in Europe has always been $A e$. albopictus. 
The importance of Ae. albopictus is constantly growing as a consequence of rapid changes in its overall distribution and virus adaptation to the vector [17]. Since the time of World War II, the Tiger mosquito was involved in several dengue and chikungunya outbreaks that occurred in Japan, Hawaii, southern China, Indian Ocean Islands, and the Indian sub-continent [18].

In temperate areas, the global spread of Ae. albopictus is a prerequisite for transmission. Furthermore, several factors may increase the risk of importation of dengue and similar mosquito-borne infections into previously disease-free areas, well beyond the tropical and subtropical belt, where the vector is present: (i) the massive increase of mosquito-borne infections such as dengue, in certain areas of the world, driven by rapid population growth and uncontrolled urbanisation [19]; (ii) the spread of dengue, chikungunya, and Zika viruses in many touristic destinations in southeast Asia, Indian Ocean Islands, Pacific Islands, and in particular Central and South America; (iii) increased human mobility, which is an important driver of longdistance virus transportation.

The article by Succo et al. is an additional example that dengue transmission can occur in Europe However, to what extent tropical vector-borne infections may cause large outbreaks or even become endemic in Europe cannot be easily predicted. In a likely scenario, autochthonous cases may appear once the virus is introduced and amplified by local mosquitoes in a permissive environment. However, implementation of vector control measures following early detection of cases, combined with the decline of mosquito activity at the beginning of the winter season, may cut down the basic reproductive number $\left(\mathrm{R}^{\circ}\right)$ and to stop transmission.

To better assess the risk of sustained transmission and persistence of Aedes-borne infections in Europe, the characteristics of the vector and the influence of climatic factors should be considered. Ae. albopictus adapts better than Ae. aegypti to temperate climate and may be implicated in outbreaks in areas where Ae. aegypti is not established. However, Ae. albopictus usually feeds on a single individual while Ae. aegypti tends to feed on more individuals during one gonotrophic cycle and only on humans. Thus, outbreaks caused by Ae. albopictus, may be more limited in size that those cause by Ae. aegypti, even if vector density is similar $[17,18]$. Moreover, vertical transmission of DENV and CHIKV from mosquitoes to their offspring is not very efficient. The low efficiency of transovarial transmission combined with the decline of mosquito activity during the cold season may explain the selflimiting nature of outbreaks occurring in temperate climate areas. Finally, even though DENV and Zika fitness for $A e$. albopictus is not negligible, it is lower than for Ae. aegypti $[20,21]$; thus the sustainability of DENV, ZIKV and, to a lesser extent, CHIKV variant transmission, in areas where Ae. albopictus is the predominant vector, is not likely to be high.
Some of the consideration reported above may appear reassuring. However, the likelihood of future occurrence of dengue and other Aedes-borne viruses in Europe will be impacted by (i) repeated introduction of the infection, (ii) climate change, which may favour overwintering of virus and mosquitoes, (iii) possible increased fitness of viruses for the Tiger mosquito, as happened for CHIKV, and (iv) the return of Ae. aegypti, which is now established Caucasian cost of the Black Sea, where it competes with Ae. albopictus and $A e$. koreicus [22]. To this regard, further expansion of $A e$. aegypti towards the Mediterranean shores may not be fully excluded.

The article by Succo et al., published in this issue of Eurosurveillance, confirms the potential risk represented by dengue and other Aedes-borne scourges to Mediterranean Europe, underlining the importance of risk assessment, enhanced surveillance aimed at early detection of transmission chains, and mosquito control programs. Though the risk of large scale outbreaks and endemicity may appear rather low for most European countries, the effect of environmental, ecological, entomological, demographic, and behavioural changes on the epidemic potential of exotic Aedes-borne infections should not be underestimated.

\section{Conflict of interest}

None declared.

\section{References}

1. Cardamatis JP. La dengue in Greece.Bull Soc Pathol Exot. 1929;22:272-92.

2. Papaevangelou G, Halstead SB. Infections with two dengue viruses in Greece in the 2oth century. Did dengue hemorrhagic fever occur in the 1928 epidemic?J Trop Med Hyg. 1977;80(3):46-51.PMID: 327086

3. Schaffner F, Mathis A. Dengue and dengue vectors in the WHO European region: past, present, and scenarios for the future. Lancet Infect Dis. 2014;14(12):1271-80.DOI: 10.1016/S14733099(14)70834-5 PMID: 25172160

4. Theiler M, Casals J, Moutousses C. Etiology of t e 192728 epidemic of dengue in Greece.Proc Soc Exp Biol Med. 1960;103(1):244-6.DOI: 10.3181/00379727-103-25474 PMID: 13837683

5. Halstead SB, Papaevangelou G. Transmission of dengue 1 and 2 viruses in Greece in 1928. Am J Trop Med Hyg. 1980;29:635-7.

6. Succo T, Leparc-Goffart I, Ferré J, Roiz DBroche BMaquart M et al. Autochthonous dengue outbreak in Nîmes, South of France, July to September 2015. Euro Surveill. 2016;21(21):30240. DOI: 10.2807/1560-7917.ES.2016.21.21.30240

7. La Ruche G, Souarès Y, Armengaud A, Peloux-Petiot F, Delaunay $P$, Desprès $P$, et al. First two autochthonous dengue virus infections in metropolitan France, September 2010. Euro Surveill. 2010;15(39):19676.PMID: 20929659

8. Schmidt-Chanasit J, Haditsch M, Schöneberg I, Günther S, Stark K, Frank C. Dengue virus infection in a traveller returning from Croatia to Germany.Euro Surveill. 2010;15(40):19677. PMID: 20946759

9. Gjenero-Margan I, Aleraj B, Krajcar D, Lesnikar V, Klobučar A, Pem-Novosel I, et al. Autochthonous dengue fever in Croatia, August-September 2010. Euro Surveill. 2011;16(9):19805.PMID: 21392489

10. Marchand E, Prat C, Jeannin C, Lafont E, Bergmann T, Flusin O, et al. Autochthonous case of dengue in France, October 2013. Euro Surveill. 2013;18(50):20661.DOI: 10.2807/1560-7917. ES2013.18.50.20661 PMID: 24342514

11. Giron S, Rizzi J, Leparc-Goffart I, Septfons A, Tine R, Cadiou B , et al. New occurrence of autochthonous cases of dengue fever 
in Southern France, August-September 2014. Bull Epidemiol Hebd (Paris). 2015;13-14:217-23.

12. Rezza G, Nicoletti L, Angelini R, Romi R, Finarelli AC, Panning $M$, et al. , CHIKV study group. Infection with chikungunya virus in Italy: an outbreak in a temperate region. Lancet. 2007;370(9602):1840-6.DOI: 10.1016/S0140-6736(07)61779-6 PMID: 18061059

13. Vazeille M, Moutailler S, Coudrier D, Rousseaux C, Khun H, Huerre M, et al. Two Chikungunya isolates from the outbreak of La Reunion (Indian Ocean) exhibit different patterns of infection in the mosquito, Aedes albopictus. PLoS One. 2007;2(11):e1168.DOI: 10.1371/journal.pone.0001168 PMID: 18000540

14. Grandadam M, Caro V, Plumet $S$, Thiberge JM, Souarès $Y$, Failloux $A B$, et al. Chikungunya virus, southeastern France. Emerg Infect Dis. 2011;17(5):910-3.DOI: 10.3201/eid1705.101873 PMID: 21529410

15. World Health Organization (WHO). WHO statement on the first meeting of the International Health Regulations (2005) (IHR 2005) Emergency Committee on Zika virus and observed increase in neurological disorders and neonatal malformations. Geneva: WHO; 1 February 2016. Available from: http://www.who.int/mediacentre/news/ statements/2016/1st-emergency-committee-zika/en/

16. Alves MJ, Fernandes PL, Amaro F, Osório H, Luz T, Parreira $P$, et al. Clinical presentation and laboratory findings for the first autochthonous cases of dengue fever in Madeira island, Portugal, October 2012. Euro Surveill. 2013;18(6):20398.PMID: 23410256

17. Rezza G. Aedes albopictus and the reemergence of dengue. BMC2012; 12:72.

18. Rezza G. Dengue and chikungunya: long-distance spread and outbreaks in naïve areas.Pathog Glob Health. 2014;108(8):34955.DOI: 10.1179/2047773214Y.0000000163 PMID: 25491436

19. Gubler DJ. Dengue, urbanization and globalization: the unholy trinity of the 21(st) Century.Trop Med Health. 2011;39(4) Suppl;3-11.DOI: 10.2149/tmh.2011-So5 PMID: 22500131

20. Moutailler S, Barré H, Vazeille M, Failloux AB. Recently introduced Aedes albopictus in Corsica is competent to Chikungunya virus and in a lesser extent to dengue virus.Trop Med Int Health. 2009;14(9):1105-9.DOI: 10.2807/1560-7917. ES.2016.21.15.30199 PMID: 19725926

21. Di Luca M, Severini F, Toma L, Boccolini D, Romi R, Remoli ME, et al. Experimental studies of susceptibility of Italian Aedes albopictus to Zika virus. Euro Surveill. 2016;21(18):30223.DOI: 10.2807/1560-7917.ES.2016.21.18.30223 PMID: 27171034

22. Ganushkina LA, Patraman IV, Rezza G, Migliorini L, Litvinov SK, Sergiev VP. Detection of Aedes aegypti, Aedes albopictus, and Aedes koreicus in the Area of Sochi, Russia.Vector Borne Zoonotic Dis. 2016;16(1):58-60.DOI: 10.1089/vbz.2014.1761 PMID: 26741323

\section{License and copyright}

This is an open-access article distributed under the terms of the Creative Commons Attribution (CC BY 4.0) Licence. You may share and adapt the material, but must give appropriate credit to the source, provide a link to the licence, and indicate if changes were made.

This article is copyright of the authors, 2016. 